\title{
Analysis of the reaction of subcutaneous tissues in rats and the antimicrobial activity of calcium hydroxide paste used in association with different substances
}

\author{
Raquel Zanin MIDENA¹, Roberto Brandão GARCIA', Bruno Cavalini CAVENAGO'1, Marina Angélica MARCIANO', \\ Paloma Gagliardi MINOTTI', Ronald ORDINOLA-ZAPATA ${ }^{1}$, Paulo Henrique WECKWERTH ${ }^{2}$, Flaviana Bombarda de \\ ANDRADE', Marco Antonio Hungaro DUARTE'
}

\begin{abstract}
1- Universidade de São Paulo, Faculdade de Odontologia de Bauru, Departamento de Dentística, Endodontia e Materiais Dentários, Bauru, SP, Brazil. 2- Universidade do Sagrado Coração, Departamento de Ciências da Saúde, Bauru, SP, Brazil.
\end{abstract}

Corresponding address: Raquel Zanin Midena - Alameda Octávio Pinheiro Brisolla, 9-75 - 17012-901 - Bauru - SP - Brazil - Phone/Fax number: 55 1432358344 - e-mail: raquelmidena@gmail.com

Submitted: February 23, 2014 - Modification: October 28, 2014 - Accepted: October 30, 2014

\section{ABSTRACT}

\begin{abstract}
$\mathrm{T}$ he aim of this study was to evaluate the subcutaneous tissue response in rats and the antimicrobial activity of intracanal calcium hydroxide dressings mixed with different substances against E. faecalis. Fifty four rats were divided into three experimental groups according to the vehicle in the calcium hydroxide treatment: $0.4 \%$ chlorohexidine in propylene glycol (PG), Casearia sylvestris Sw in PG and calcium hydroxide+PG (control group). The pastes were placed into polyethylene tubes and implanted into the subcutaneous tissue. After 7, 14 and 30 days, the samples were processed and histologically evaluated (hematoxylin and eosin). The tissue surface in contact with the material was analyzed, and the quantitative analysis determined the volume density occupied by the inflammatory infiltrate (giant cells, polymorphonuclear cells and mononuclear cells), fibroblasts, collagen fibers and blood vessels. For the antimicrobial analysis, 20 dentin blocks infected with $\mathrm{E}$. faecalis were treated with calcium hydroxide pastes in different vehicles; $0.4 \%$ chlorhexidine in PG, PG, extract from Casearia sylvestris Sw in PG and a positive control (infection and without medication) for 7 days. The efficiency of the pastes was evaluated by the live/dead technique and confocal microscopy. The results showed that $0.4 \%$ chlorhexidine induced a higher inflammatory response than the other groups. The Casearia sylvestris Sw extract showed satisfactory results in relation to the intensity of the inflammatory response. In the microbiological test, there were no statistical differences between the evaluated intracanal dressings and the percentage of bacterial viability was between 33 and $42 \%$. The control group showed an $86 \%$ viability. Antimicrobial components such as chlorhexidine or Casearia sylvestris Sw did not improve the antimicrobial activity against $\mathrm{E}$. faecalis in comparison to the calcium hydroxide+PG treatment. In addition, the incorporation of chlorhexidine in the calcium hydroxide paste promoted the highest inflammatory response.
\end{abstract}

Key words: Calcium hydroxide. Chlorhexidine. Endodontics. Materials testing.

\section{INTRODUCTION}

In the presence of pulp necrosis, the whole root canal system presents contamination by microorganisms and their products ${ }^{16}$. The removal of these irritants is usually performed with a biomechanical preparation and antimicrobial solutions ${ }^{4,28}$. Due to the limitations of this technique in consistently eliminating the root canal infection, the use of an intracanal medication is necessary to continue the antisepsis process ${ }^{4}$. The use of calcium hydroxide $(\mathrm{CH})$ is advantageous and accepted because of its antiseptic and biological actions. The antimicrobial and biological properties 
of $\mathrm{CH}$ occurred due to its high $\mathrm{pH}$ level, which provides microbial inhibition ${ }^{8}$. Another important factor is related to lipopolysaccharide inhibition ${ }^{24}$. In addition, the calcium release plays an important role in the formation of mineralized tissue ${ }^{20}$.

Several substances have been mixed with calcium hydroxide to improve some of its properties such as viscosity, radiopacity, antimicrobial spectrum action and ionic dissociation rate $\mathrm{r}^{3,9,15}$. The alkaline $\mathrm{pH}$ level is approximately 12.6 , however, some types of bacteria such as Enterococcus faecalis is considered resistant to the antimicrobial action of calcium hydroxide inside the root canals ${ }^{18}$.

Chlorhexidine digluconate is a bisguanide which is known for its antimicrobial action against bacteria ${ }^{26}$. The association of chlorhexidine to calcium hydroxide seems to increase the efficiency of calcium hydroxide paste against Enterococcus faecalis ${ }^{11}$. However, chlorhexidine used alone has caused damage to the DNA in oral mucosa cells and leukocytes ${ }^{14}$, and the association of calcium hydroxide with chlorhexidine increases the production of reactive oxygen ${ }^{2}$, which can result in increased tissue aggression ${ }^{28}$.

The search for herbal medicines for use in medicine and dentistry is intense, including its uses as an intracanal dressing ${ }^{13}$. One of the herbs currently being studied is Casearia sylvestris Swart (Sw). It is a plant that originates from Latin America and can be found from Mexico to Argentina. In Brazil, it is found in abundance, it is a species very common in the State of São Paulo ${ }^{25}$. This plant extract has shown anti-inflammatory and antimicrobial actions ${ }^{22}$. In relation to its chemical composition, essential oils (terpenes and triterpenes), saponins, fatty acids, tannins, resins, anthocyanosides and flavonoids were found ${ }^{25}$. Some chemical components in particular can take direct action against E. faecalis, such as tannins, flavonoids and essential oils.

The addition of Casearia sylvestris extract and chlorhexidine to calcium hydroxide does not interfere with its physico-chemical properties ${ }^{6}$. The aim of this study was to analyze the biocompatibility and the antimicrobial action of Casearia sylvestris Sw (Guaçatonga) and chlorhexidine mixed with calcium hydroxide paste.

\section{MATERIAL AND METHODS}

This study evaluated three calcium hydroxide pastes: Group 1 - calcium hydroxide (Merck KGaA, Darmstadt, Germany) mixed with $0.4 \%$ chlorhexidine in propylene glycol (Specific Pharmacy, Bauru, SP, Brazil); Group 2 - calcium hydroxide (Merck KGaA, Darmstadt, Germany) mixed with the extract from Casearia sylvestris $\mathrm{Sw}$ in propylene glycol (Max Pharma Trade and Import of Pharmaceutical Ingredients/Inputs, São Paulo, SP, Brazil); Group 3 (control) - calcium hydroxide (Merck KGaA, Darmstadt, Germany) mixed with propylene glycol (Specific Pharmacy, Bauru, SP, Brazil).

The Casearia sylvestris Sw extract utilized in this study was obtained from the Max Pharma pharmaceutical laboratory (Max Pharma Trade and Import of Pharmaceutical Ingredients/Inputs, São Paulo, SP, Brazil) and was produced in accordance with the Brazilian pharmacopeia. The Casearia sylvestris Sw leaves were subjected to a drying process in a circulating air, anatomical oven under a controlled temperature until a constant weight was achieved. The leaves were ground with grinder knives before being used in the preparation of the extract. The crushed product was subjected to maceration for propylene glycol extraction applications, where the powder's proportion was 25 grams for each $200 \mathrm{~mL}$ of propylene glycol. This extract solution remained in contact with the powder for 8 days with sporadic agitation in an amber glass bottle, to avoid possible interference from light, at a room temperature of approximately $25^{\circ} \mathrm{C}$.

The pastes were prepared on a sterile glass plate using $3.0 \mathrm{~g}$ of calcium hydroxide powder (Merck KGaA, Darmstadt, Germany) for each $1.75 \mathrm{~mL}$ of the substances tested in each group.

\section{Tissue analysis}

This study was approved by the Ethical Committee for Teaching and Research on Animals. A total of 54 Wistar rats (Rattus norvegicus albinus) were divided into three experimental groups each of 18 animals, according to the division of the groups mentioned above.

The animals were anesthetized with a combination of Ketamine hydrochloride (Dopalen ${ }^{\circledR}$ - Vetbrands, CEVA, Paulínia, SP, Brazil) and Xylazine hydrochloride (Anasedan ${ }^{\circledR}$ - Vetbrands, CEVA, Paulínia, SP, Brazil). These substances were used in a concentration of $0.1 \mathrm{~mL}$ of solution for every 100 grams of animal weight. A manual trichotomy was performed on the dorsal region and was disinfected with an iodized alcohol solution. A longitudinal incision was made in the middle of the back of each region, with a no. 15 scalpel blade (Embramac, - Empresa Brasileira de Materiais Cirúrgicos, Campinas, SP, Brazil).

After manipulation, the pastes were placed in polyethylene tubes measuring $1 \mathrm{~mm}$ in internal diameter, $2.0 \mathrm{~mm}$ in external diameter and $10 \mathrm{~mm}$ in length (Embramed Ind. Com. Ltda., São Paulo, $\mathrm{SP}$, Brazil) which were sterilized with ethylene oxide. Then each polyethylene tube, filled with one of the pastes, was placed in an exchange cannula, which was inducted into the open space until it reached a 
depth of $18 \mathrm{~mm}$ in the subcutaneous tissue, causing tissue dilatation. Two tubes form the same group, one for the left side and one for the right side, were deployed into the back of each animal.

The implants were carefully deposited perpendicular to the line of incision, to avoid deportation and to decrease mobility. The incisions were sutured with 4.0 silk thread (Ethicon Professional Products, Johnson \& Johnson Ltda., São Paulo, SP, Brazil).

Six animals were used for each experimental period (7, 14 and 30 days). After the experimental time, the animals were killed with an excessive dose of Ketamine hydrochloride (Dopalen ${ }^{\circledR}$ - Vetbrands, CEVA, Paulínia, SP, Brazil). A new trichotomy was made on the dorsal region and a dissection of the implant area with a normal safety margin of the surrounding tissue. The tissue containing the implanted tubes was placed on paper and maintained fixed in a $10 \%$ formalin buffer (Merck KGaA, Darmstadt, Germany) for 7 days.

Next, the tissue samples were subjected to conventional histotechnical processing. Five micrometer thicknesses of serial sections were obtained from the capsule area.

The histological sections were stained with the hematoxylin and eosin technique and evaluated using a light microscope (Aristoplan, Leitz Wetzlar, Germany). A calibrated examiner analyzed the sections in a quantitative manner.

To evaluate the inflammatory response, the tissue surfaces in contact with the material were analyzed, and those areas were analyzed in four microscopical fields of two sections.

Quantitative analysis using an optical microscope (Aristoplan, Leitz Wetzlar, Germany) with a $100 \times$ objective and $8 \times$ Zeiss $\mathrm{Kpl}$ eyepiece containing a Zeiss II integration grid with 100 points symmetrically distributed over a quadrangular area, determined the volume density occupied by the inflammatory infiltrate (giant cells, polymorphonuclear cells and mononuclear cells), fibroblasts, collagen fibers and blood vessels ${ }^{19,21}$.

The Kruskal-Wallis and Dunn tests were utilized for the analysis of the quantitative analysis. The level of significance was set at $\mathrm{P}<0.05$ and the Prisma 5.0 software (GraphPad Software Inc, La Jolla, CA, USA) was utilized as the analytical tool.

\section{Microbiological analysis}

Twenty blocks of sterile bovine dentin were used in the experimental procedures. The measurements of the blocks were approximately $4 \times 4 \times 2 \mathrm{~mm}$. The dentin blocks were made from bovine incisors, sterilized by autoclaving. The dentin segments were treated with $1 \%$ sodium hypochlorite for 30 minutes and $17 \%$ EDTA for 5 minutes. After that the blocks were immersed in $\mathrm{BHI}$ broth (Brain Hearth Infusion
- BD - Becton, Dickinson and Company, Sparks MD, USA) culture containing Enterococcus faecalis ATCC 25912 (American Type Culture Collection, Manassas, VA) standardized by the 0.5 McFarland scale $\left(1.5 \times 10^{8}\right.$ bacteria per $\left.\mathrm{mL}\right)$ and incubated for 21 days. The new culture broth of E. faecalis, obtained by overnight incubation and standardized with the 0.5 McFarland scale was refreshed every 3 days.

At the end of the experimental period, the infected blocks were removed from the culture broths, rinsed 3 times with a sterile, buffered saline solution then dried with absorbent paper and randomly distributed over the surfaces of sterile Petri dishes in accordance with each test group: Group 1 - Calcium hydroxide (Merck KGaA, Darmstadt, Germany) mixed with $0.4 \%$ chlorhexidine in propylene glycol (Specific Pharmacy, Bauru, $\mathrm{SP}$, Brazil); Group 2 - calcium hydroxide mixed with the extract from Casearia sylvestris $\mathrm{Sw}$ in propylene glycol (Max Pharma Trade and Importer of Pharmaceutical Ingredients/Inputs. Ltda., São Paulo, SP, Brazil); Group 3 - calcium hydroxide (Merck KGaA, Darmstadt, Germany) mixed with propylene glycol (Specific Pharmacy, Bauru, SP, Brazil); Group 4 - positive control (with infection and without medication).

The blocks from groups 1-3 had their surfaces filled with their respective calcium hydroxide paste using the different vehicles. The blocks were again maintained at $37^{\circ} \mathrm{C}$ for one week at $100 \%$ humidity. After this period, the pastes were removed by irrigation with $2 \mathrm{~mL}$ of sterile water and then dried with sterile paper point cones.

For the bacterial viability analysis a confocal laser scanning microscope was used. The samples were stained using the Syto-9/Propidium iodide (PI) technique (Live/Dead, Baclight; Invitrogen, Carlsbad, CA, USA). SYTO-9 is a green, fluorescent nucleic acid stain which generally labels all live microrganisms. PI is a red, fluorescent nucleic acid stain that penetrates only cells with damaged membranes, highlighting the dead micro-organisms. The treated dentine samples were stained with 50 $\mu \mathrm{L}$ of the dyes for $10 \mathrm{~min}$ at room temperature in a dark environment. Four 40X confocal pictures were obtained from each sample using a $40 \mathrm{X}$ oil lens (Leica TCS-SPE; Microsystems GmbH, Mannheim, Germany). The scanning was performed by using a $1 \mu \mathrm{m}$ step-size in a $512 \times 512$ pixel format, for a total of 20 images analyzed for each medication. The obtained biofilm images represented an area of $275 \times 275 \mu \mathrm{m}^{2}$. For quantification purposes, the Bioimage-L software (http://www.bioimagel.com) was used to determine the percentage of live cells ${ }^{5}$. The Kruskal-Wallis and Dunn tests were utilized for the analysis of the antimicrobial activity. The significance level was set at $P<0.05$ and the Prisma 
5.0 software (GraphPad Software Inc, La Jolla, CA, USA) was used as the analytical tool.

\section{RESULTS}

Inflammatory reaction

The values and statistical comparisons concerning the intensity of the inflammatory cells, collagen fibers, fibroblasts and blood vessels between the groups in each experimental period and between periods for each group are presented in Table 1 and Table 2. At the initial periods, it was possible to observe amorphous tissue in the contact region with the material, suggestive of coagulation necrosis,

Table 1- Median, maximum and minimum values obtained from the inflammatory reaction analysis in the three experimental periods

\begin{tabular}{cccccccccc}
\hline & \multicolumn{3}{c}{ Giant cells } & \multicolumn{3}{c}{ Inflammatory cells } \\
& \multicolumn{3}{c}{} & \multicolumn{3}{c}{ Mononuclear cells } & \multicolumn{3}{c}{ Polymorphonuclear cells } \\
& $\mathbf{7}$ days & $\mathbf{1 4}$ days & $\mathbf{3 0}$ days & $\mathbf{7}$ days & $\mathbf{1 4}$ days & $\mathbf{3 0}$ days & $\mathbf{7}$ days & $\mathbf{1 4}$ days & $\mathbf{3 0}$ days \\
\hline $\mathrm{CH}+\mathrm{CLX} 0.4 \%$ & $1.125^{\mathrm{A} ; 1,2}$ & $1.563^{\mathrm{A} ; 1}$ & $0.0000^{\mathrm{A} ; 2}$ & $14.44^{\mathrm{A} ; 1}$ & $11.25^{\mathrm{AB} ; 1}$ & $5.000^{\mathrm{A} ; 2}$ & $0.6250^{\mathrm{A} ; 1}$ & $0.2500^{\mathrm{AB} ; 1,2}$ & $0.0000^{\mathrm{A} ; 2}$ \\
& $(0.0000-$ & $(0.0000-$ & $(0.0000-$ & $(6.250-$ & $(7.500-$ & $(4.250-$ & $(0.0000-$ & $(0.0000-$ & $(0.0000-$ \\
& $3.500)$ & $8.250)$ & $1.250)$ & $19.50)$ & $24.75)$ & $7.750)$ & $1.750)$ & $1.000)$ & $0.2500)$ \\
$\mathrm{CH}+\mathrm{CS}$ & $0.1250^{\mathrm{A} ; 1}$ & $0.0000^{\mathrm{B} ; 1,2}$ & $0.0000^{\mathrm{A} ; 2}$ & $14.32^{\mathrm{A} ; 1}$ & $9.875^{\mathrm{A} ; 1}$ & $1.563^{\mathrm{B} ; 2}$ & $0.0000^{\mathrm{AB} ; 1}$ & $0.0000^{\mathrm{A} ; 1}$ & $0.0000^{\mathrm{A} ; 1}$ \\
& $(0.0000-$ & $(0.0000-$ & $(0.0000-$ & $(9.250-$ & $(3.250-$ & $(0.5000-$ & $(0.0000-$ & $(0.0000-$ & $(0.0000-$ \\
& $3.250)$ & $0.5000)$ & $0.0000)$ & $42.50)$ & $15.50)$ & $4.750)$ & $0.5000)$ & $0.2500)$ & $0.2500)$ \\
& $2.000^{\mathrm{A} ; 1}$ & $0.6250^{\mathrm{AB} ; 1,2}$ & $0.0000^{\mathrm{A} ; 2}$ & $17.25^{\mathrm{A} ; 1}$ & $13.75^{\mathrm{B} ; 1}$ & $1.188^{\mathrm{B} ; 2}$ & $0.0000^{\mathrm{B} ; 1}$ & $0.6875^{\mathrm{B} ; 1}$ & $0.0000^{\mathrm{A} ; 1}$ \\
$\mathrm{CH}+\mathrm{PG}$ & $(0.0000-$ & $(0.0000-$ & $(0.0000-$ & $(7.750-$ & $(5.500-$ & $(0.2500-$ & $(0.0000-$ & $(0.0000-$ & $(0.0000-$ \\
& $5.500)$ & $2.000)$ & $0.2500)$ & $28.00)$ & $16.75)$ & $4.000)$ & $1.500)$ & $1.750)$ & $0.5000)$ \\
\hline
\end{tabular}

Different uppercase letters in columns represent statistically significant differences between the materials from each period. Different numbers represent statistically significant differences between periods for each material

$\mathrm{CH}$ : Calcium hydroxide; CLX: Chlorhexidine; CS: Casearia sylvestris; PG: Propylene glycol

Table 2- Median, maximum and minimum values obtained from the histological events shown in connective tissue analysis in the three experimental periods

\begin{tabular}{cccccccccc}
\hline & \multicolumn{3}{c}{ Collagen fibers } & \multicolumn{3}{c}{ Histological events } \\
& \multicolumn{3}{c}{} & \multicolumn{3}{c}{ Fibroblasts } & \multicolumn{3}{c}{ Blood vessels } \\
& $\mathbf{7}$ days & $\mathbf{1 4}$ days & $\mathbf{3 0}$ days & $\mathbf{7}$ days & $\mathbf{1 4}$ days & $\mathbf{3 0}$ days & $\mathbf{7}$ days & $\mathbf{1 4}$ days & $\mathbf{3 0}$ days \\
\hline $\mathrm{CH}+\mathrm{CLX} 0,4 \%$ & $52.07^{\mathrm{A} ; 1}$ & $42.38^{\mathrm{A} ; 1}$ & $63.75^{\mathrm{A} ; 2}$ & $5.255^{\mathrm{A} ; 1}$ & $3.625^{\mathrm{A} ; 1}$ & $7.938^{\mathrm{A} ; 2}$ & $0.8750^{\mathrm{A} ; 1}$ & $0.5000^{\mathrm{A} ; 1}$ & $1.125^{\mathrm{A} ; 1}$ \\
& $(43.50-$ & $(17.50-$ & $(57.75-$ & $(3.500-$ & $(1.000-$ & $(4.500-$ & $(0.0000-$ & $(0.0000-$ & $(0.5000-$ \\
& $58.00)$ & $54.75)$ & $71.75)$ & $6.750)$ & $7.500)$ & $11.00)$ & $5.130)$ & $3.500)$ & $1.750)$ \\
$\mathrm{CH}+\mathrm{CS}$ & $46.50^{\mathrm{A} ; 1}$ & $56.63^{\mathrm{B} ; 1}$ & $53.06^{\mathrm{B} ; 1}$ & $7.875^{\mathrm{B} ; 1}$ & $7.500^{\mathrm{B} ; 1}$ & $7.563^{\mathrm{A} ; 1}$ & $1.250^{\mathrm{A} ; 1}$ & $0.7500^{\mathrm{A} ; 2}$ & $0.8125^{\mathrm{A} ; 1,2}$ \\
& $(20.25-$ & $(42.25-$ & $(39.25-$ & $(2.500-$ & $(4.250-$ & $(6.250-$ & $(0.0000-$ & $(0.0000-$ & $(0.5000-$ \\
& $61.25)$ & $70.00)$ & $69.50)$ & $10.00)$ & $10.75)$ & $8.750)$ & $2.750)$ & $1.250)$ & $1.500)$ \\
$\mathrm{CH}+\mathrm{PG}$ & $48.50^{\mathrm{A} ; 1}$ & $51.75^{\mathrm{B} ; 1}$ & $68.00^{\mathrm{A} ; 2}$ & $8.565^{\mathrm{B} ; 1}$ & $5.063^{\mathrm{A} ; 2}$ & $8.125^{\mathrm{A} ; 1}$ & $0.2500^{\mathrm{B} ; 1}$ & $0.0625^{\mathrm{A} ; 1}$ & $0.3750^{\mathrm{B} ; 1}$ \\
& $(36.25-$ & $(45.50-$ & $(53.50-$ & $(4.000-$ & $(2.000-$ & $(4.500-$ & $(0.0000-$ & $(0.0000-$ & $(0.0000-$ \\
& $52.25)$ & $67.50)$ & $79.00)$ & $10.75)$ & $8.750)$ & $10.50)$ & $1.500)$ & $1.250)$ & $0.5000)$ \\
\hline
\end{tabular}

Different uppercase letters in columns represent statistically significant differences between the materials in each period. Different numbers represent statistically significant differences between periods for each material

$\mathrm{CH}$ : Calcium hydroxide; CLX: Chlorhexidine; CS: Casearia sylvestris; PG: Propylene glycol

Table 3- Minimum, median, maximum and mean of the percentage of living cells after contact with the experimental substances

\begin{tabular}{ccccc}
\hline Live cells (\%) & CH + CLX 0,4 \% & CH + CS & CH + PG & Positive control \\
\hline Minimum & 3.149 & 4.968 & 1.953 & 53.58 \\
Median & 42.45 & 34.58 & 33.59 & 86.62 \\
Maximum & 77.84 & 80.96 & 81.22 & 93.18 \\
Mean & 43.08 & 40.55 & 36.89 & 83.65 \\
\hline
\end{tabular}

$\mathrm{CH}$ : Calcium hydroxide; CLX: Chlorhexidine; CS: Casearia sylvestris; PG: Propylene glycol 

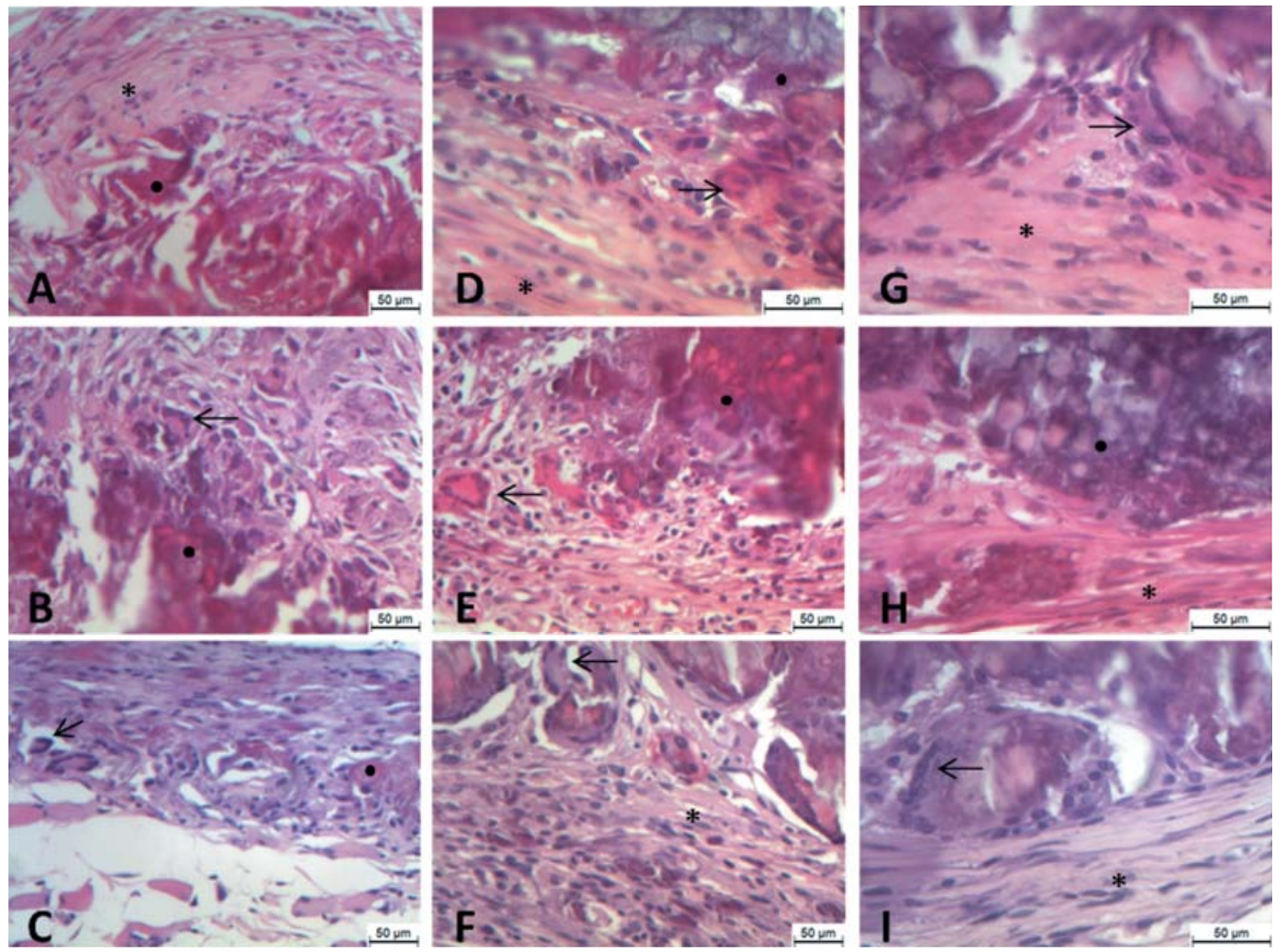

Figure 1- Week one subcutaneous tissue response of the evaluated intracanal dressings (7 days). Chlorhexidine $0.4 \%+$ calcium hydroxide (A); Casearia sylvestris Sw+calcium hydroxide (B); Propylene glycol+calcium hydroxide (C). Fibrocellular tissue $\left({ }^{*}\right)$, macrophage infiltration (arrows) and material remnants $(\bullet$ ) can be observed. At 14 days, a decrease in the inflammatory infiltrate (arrows) and a discrete increase in fibrocellular tissue $\left(^{*}\right)$ in comparison to the 7 day period were observed. Chlorhexidine $0.4 \%+$ calcium hydroxide (D); Casearia sylvestris Sw+calcium hydroxide (E); Propylene glycol+calcium hydroxide (F). After 30 days, organized subcutaneous tissue is evident. Chlorhexidine $0.4 \%+c a l c i u m$ hydroxide (G) presenting giant cells (arrow). Fibrocellular tissue $\left(^{*}\right)$ is present in Casearia sylvestris Sw+calcium hydroxide (H) and propylene glycol+calcium hydroxide (I)

probably due to the alkaline action of the calcium hydroxide. Overall, the lowest values were found at the 30 day period for all pastes tested. In the 7 day period there were no statistically significant differences $(P>0.05)$ among the tested pastes $(P>0.05)$, however, during the periods of 14 to 30 days, statistically significant differences were found $(P<0.05)$. A representative picture of the inflammatory reaction is shown in Figure 1.

\section{Microbiological analysis}

Table 3 shows the minimum, median, maximum and mean of the percentage of living cells after contact with the different calcium hydroxide pastes. All the pastes presented a significantly $(P<0.05)$ lower percentage of live cells than the control. There were no statistically significant differences $(P>0.05)$ between the medications. Figure 2 represents images obtained from the biofilms after treatment with the different pastes.

\section{DISCUSSION}

The objective of this study was to compare the effects of the addition of chlorhexidine or the extract from Casearia sylvestris Sw in propylene glycol to calcium hydroxide on the biocompatibility and antimicrobial activity of the pastes. In endodontic therapy, chlorhexidine is used in concentrations of $0.2 \%$ to $2.0 \%{ }^{29}$. Chlorhexidine has an antimicrobial action in low concentrations $(0.006 \%)$, and its effectiveness decreases in line with the reduction in concentration. This shows that there is a consensus among the choice of chlorhexidine concentrations used both as an irrigant solution or intracanal medication ${ }^{1}$. The findings for the inflammatory reaction of all groups tested, including the control group at 7 days, was more intense than at 14 and 30 days, as reported by a previous study ${ }^{30}$.

For the period of 14 days, the inflammatory reaction intensity values for all groups showed significant differences. For the tested materials, the group of Casearia sylvestris Sw extract in propylene glycol proved to be less irritating than 

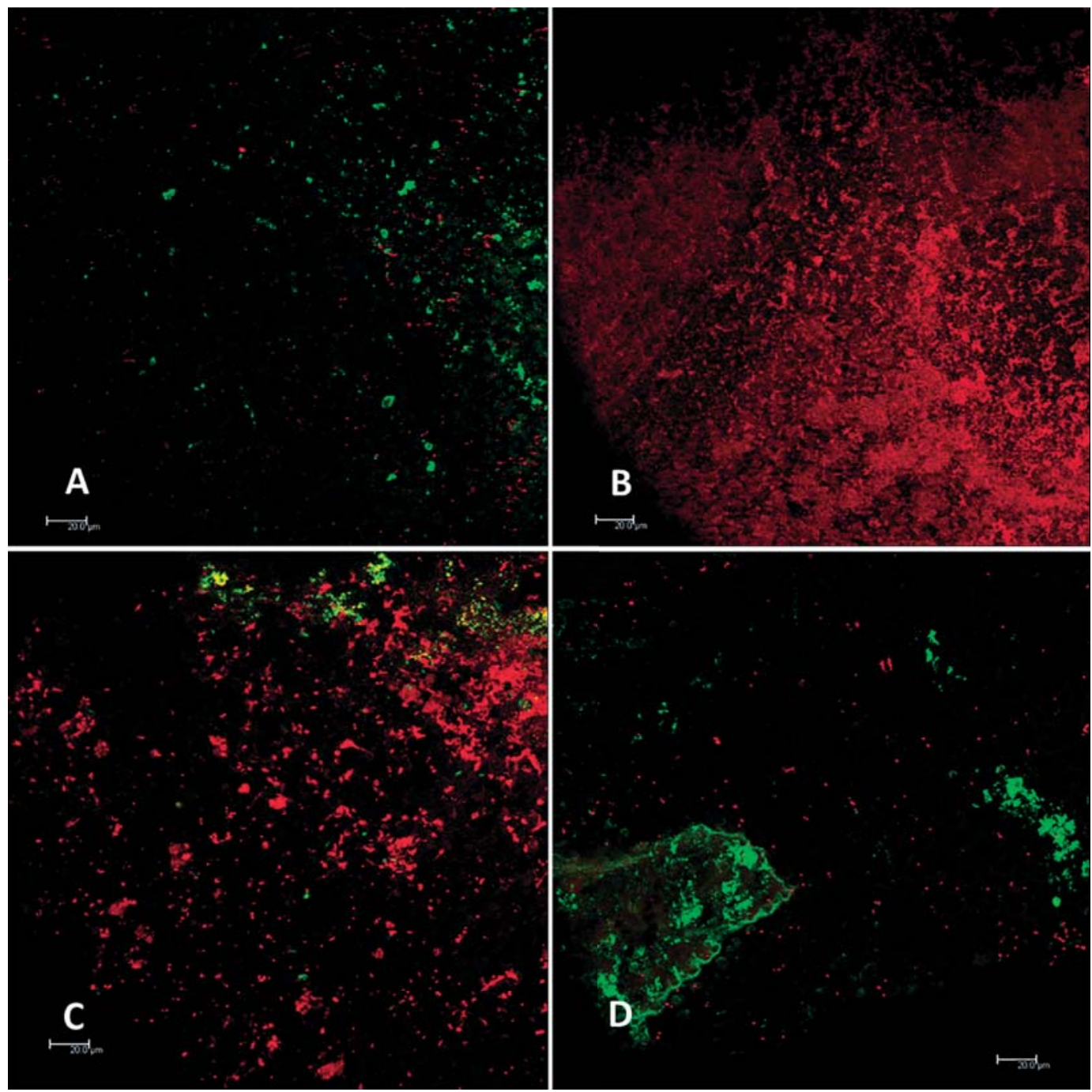

Figure 2- Representative confocal pictures after treatment with chlorhexidine $0.4 \%+$ calcium hydroxide $(A)$; Casearia sylvestris Sw+calcium hydroxide (B); Propylene glycol+calcium hydroxide (C); Positive control (D). Dead cells are observed as red and live cells are observed as green

the others, which is contrary to another study ${ }^{26}$. The differences in the results can be attributed to the fact that the previous study ${ }^{26}$ used a pure extract, and in our study the association with the calcium hydroxide paste could have reduced the cytotoxic effect. The characteristics of the inflammatory infiltrate during this period were also defined by the presence of giant cells and macrophages, however, the beginning of some tissue organization was detected in the three groups.

At the 30 day period, there was a decrease in the intensity of the inflammatory response in all the groups. The $0.4 \%$ chlorhexidine group reaction remained high compared to the other groups, establishing a statistically significant difference between groups 1 and 3 . Such differentiation can be linked to the severity of the tissue injury by the chlorhexidine substance ${ }^{12}$. The increase in the percentage of chlorhexidine mixed with calcium hydroxide was noted; proportionally increasing the intensity caused an inflammatory reaction.
Concentrations greater than $0.5 \%$, chlorhexidine can produce tissue necrosis and the inflammatory process is more intense in slowing the healing process $^{12,23,27}$. For the Casearia sylvestris extract group, a reduction of the inflammatory infiltrate occurred, probably due to its anti-inflammatory potential originating from its essential oils ${ }^{22}$ and, in addition, the extract from this plant does not have a genotoxic effect ${ }^{17}$.

With regards to the antimicrobial analysis of the paste, the Casearia sylvestris Sw extract group showed the lowest performance against $E$. faecalis compared to the other pastes used in the experiment, suggesting that this vehicle would not be adequate for the preparation of calcium hydroxide, especially to provoke an antimicrobial action, although it had a satisfactory result in the inflammatory response.

The $0.4 \%$ chlorhexidine in the propylene glycol group had a poor performance with the paste, suggesting that the use of propylene glycol as a 
vehicle reduces its antimicrobial efficiency, probably due to a reduction of the ability of the hydroxyl ion's diffusion of calcium hydroxide in this vehicle. A possible reason is that pastes treated with propylene glycol promote a slower release of hydroxyl ions ${ }^{30}$. It should be stressed that Enterococcus faecalis is a microorganism resistant to $\mathrm{pHs}$ up to the magnitude of $11.0^{10,18}$, which would explain the smaller antimicrobial action of the pastes with propylene glycol that favor a lower $\mathrm{pH}$ level ${ }^{6}$.

\section{CONCLUSION}

Antimicrobial components such as chlorhexdine and Casearia sylvestris did not improve antimicrobial activity against $\mathrm{E}$. faecalis in comparison to the calcium hydroxide + propylene glycol medication. In addition to this, the incorporation of chlorhexidine in the calcium hydroxide paste gave the highest inflammatory response.

\section{REFERENCES}

1- Agerbaek N, Melsen B, Rolla G. Application of chlorhexidine by oral irrigation systems. Scand J Dent Res. 1975;83:284-7.

2- Barbin LE, Saquy PC, Guedes DF, Sousa-Neto MD, Estrela C, Pécora J. Determination of para-chloroaniline and reactive oxygen species in chlorhexidine and chlorhexidine associated with calcium hydroxide. J Endod. 2008;34:1508-14.

3- Basrani B, Ghanem A, Tjäderhane L. Physical and chemical properties of chlorhexidine and calcium hydroxide-containing medications. J Endod. 2004;30:413-7.

4- Bystrom A, Claesson R, Sundqvist G. The antibacterial effect of camphorated paramonochlorophenol, camphorated phenol and calcium hydroxide in the treatment of infected root canals. Endod Dent Traumatol. 1985;1:170-5.

5- Chávez de Paz LE. Image analysis software based on color segmentation for characterization of viability and physiological activity of biofilms. Appl Environ Microbiol. 2009;75:1734-9.

6- Duarte MA, Midena RZ, Zeferino MA, Vivan RR, Weckwerth $\mathrm{PH}$, Santos $\mathrm{F}$, et al. Evaluation of $\mathrm{pH}$ and calcium ion release of calcium hydroxide pastes containing different substances. J Endod. 2009;35:1274-7.

7- Esteves I, Souza I, Rodrigues M, Cardoso LG, Santos LS, Sertie JA, et al. Gastric antiulcer and anti-inflammatory activities of the essential oil from Casearia sylvestris Sw. J Ethnopharmacol. 2005;101:191-6.

8- Estrela C, Sydney GB, Bammann L, Felippe Júnior O. Mechanism of action of calcium and hydroxyl ions of calcium hydroxide on tissue and bacteria. Braz Dent J. 1995;6:85-90.

9- Estrela C, Sydney GB, Pesce HF, Felippe Júnior O. Dentinal diffusion of hydroxyl ions of various calcium hydroxide pastes. Braz Dent J. 1995;6:5-9.

10- Evans M, Davies JK, Sundqvist G, Figdor D. Mechanisms involved in the resistance of Enterococcus faecalis to calcium hydroxide. Int Endod J. 2002;35:221-8.
11- Evans MD, Baumgartner JC, Khemaleelakul SU, Xia T. Efficacy of calcium hydroxide: chlorhexidine paste as an intracanal medication in bovine dentin. J Endod. 2003;29:338-9.

12- Faria G, Celes MR, De Rossi A, Silva LA, Silva JS, Rossi MA. Evaluation of chlorhexidine toxicity injected in the paw of mice and added to cultured 1929 fibroblasts. J Endod. 2007;33:715-22. 13- Gentil M, Pereira JV, Sousa YT, Pietro R, Neto MD, Vansan LP, et al. In vitro evaluation of the antibacterial activity of Arctium lappa as a phytotherapeutic agent used in intracanal dressings. Phytother Res. 2006;20:184-6.

14- Grassi TF, Camargo EA, Salvadori DM, Marques ME, Ribeiro DA. DNA damage in multiple organs after exposure to chlorhexidine in Wistar rats. Int J Hyg Environ Health. 2007;210:163-7.

15- Guerreiro-Tanomaru JM, Chula DG, Pontes Lima RK, Berbert FL, Tanomaru-Filho M. Release and diffusion of hydroxyl ion from calcium hydroxide-based medicaments. Dent Traumatol. 2012;28:320-3.

16- Haapasalo M, Qian W, Portenier I, Waltimo T. Effects of dentin on the antimicrobial properties of endodontic medicaments. J Endod. 2007;33:917-25.

17- Maistro EL, Carvalho JC, Mantovani MS. Evaluation of the genotoxic potential of the Casearia sylvestris extract on HTC and V79 cells by the comet assay. Toxicol In Vitro. 2004;18:337-42. 18- McHugh CP, Zhang P, Michalek S, Eleazer PD. pH required to kill Enterococcus faecalis in vitro. J Endod. 2004;30:218-9.

19- Minotti PG, Ordinola-Zapata R, Midena RZ, Marciano MA, Cavenago BC, Bramante CM, et al. Rat subcutaneous tissue response to calcium silicate containing different arsenic concentrations. J Appl Oral Sci. 2015;23:42-8

20- Mizuno M, Banzai Y. Calcium ion release from calcium hydroxide stimulated fibronectin gene expression in dental pulp cells and the differentiation of dental pulp cells to mineralized tissue forming cells by fibronectin. Int Endod J. 2008;41:933-8. 21- Pereira MS, Rossi MA, Cardoso CR, Silva JS, Bezerra da Silva LA, Kuga MC, et al. Cellular and molecular tissue response to triple antibiotic intracanal dressing. J Endod. 2014;40:499-504. 22- Schneider NF, Moura NF, Colpo T, Flach A. Composição química e atividade antimicrobiana do óleo volátil de Casearia sylvestris Swart. Rev Bras Farm. 2006;87:112-4.

23- Silva RA, Assed S, Nelson-Filho P, Silva LA, Consolaro A. Subcutaneous tissue response of isogenic mice to calcium hydroxide-based pastes with chlorhexidine. Braz Dent J. 2009;20:99-106.

24- Tanomaru JM, Leonardo MR, Tanomaru Filho M, Bonetti Filho I, Silva LA. Effect of different irrigation solutions and calcium hydroxide on bacterial LPS. Int Endod J. 2003;36:733-9.

25- Teske M, Trentini AM. Compêndio de fitoterapia. $3^{a}$ ed. Colombo: Herbarium Laboratório Botânico; 1997.

26- Vianna ME, Gomes BP, Berber VB, Zaia AA, Ferraz CC, Souza-Filho FJ. In vitro evaluation of the antimicrobial activity of chlorhexidine and sodium hypochlorite. Oral Surg Oral Med Oral Pathol Oral Radiol Endod. 2004;97:79-84.

27- Waris G, Ahsan H. Reactive oxygen species: role in the development of cancer and various chronic conditions. J Carcinog. $2006 ; 5: 14$.

28- Zamany A, Safavi K, Spångberg LS. The effect of chlorhexidine as an endodontic disinfectant. Oral Surg Oral Med Oral Pathol Oral Radiol Endod. 2003;96:578-81.

29- Zehnder M. Root canal irrigants. J Endod. 2006;32:389-98. 30- Zmener O, Guglielmotti MB, Cabrini RL. Biocompatibility of two calcium hydroxide-based endodontic sealers: a quantitative study in the subcutaneous connective tissue of the rat. J Endod. $1988 ; 14: 229-35$. 